Modern Europe Hitler's Economy: Nazi Work Creation Programs, 1933-1936. by Dan P. Silverman. Cambridge, MA: Harvard University Press, 1998. Pp. 384. 45.00.

\author{
Ritschl, Albrecht
}

DOI: https://doi.org/10.1017/s0022050700024293

Posted at the Zurich Open Repository and Archive, University of Zurich ZORA URL: https://doi.org/10.5167/uzh-154517

Journal Article

Published Version

Originally published at:

Ritschl, Albrecht (1999). Modern Europe Hitler's Economy: Nazi Work Creation Programs, 1933-1936.

by Dan P. Silverman. Cambridge, MA: Harvard University Press, 1998. Pp. 384. 45.00.Journalof EconomicHistory, 59(4 $1104-1105$.

DOI: https://doi.org/10.1017/s0022050700024293 
they strove for a sympathetic understanding of the peasant commune, among many other economic institutions, as the logical result of specific circumstantial conjunctures. But this was not the same as suggesting that the peasant commune was right for all times and places; most typically, the exact converse was argued. After all, the Russian countryside was hardly a byword for economic or political virtue in those days.

Readers of this journal will probably take greater exception to the narrative of economic history which underpins the theoretical discussion. "Modern researchers," according to Kingston-Mann, "have demonstrated beyond question that (1) the extinction of common rights was not necessarily accompanied by improvement in husbandry, and (2) common rights were not incompatible with economic change" (p. 16). It is hard to disagree with such a limp generalization. But it is easier to wonder whether she is right to treat as established fact Robert Allen's argument that England's agricultural revolution was perpetrated by peasants (pp. 17,25), to dismiss as "a flight of fancy" the suggestion that English enclosure was basically peaceful and even amicable (p. 63), and to jump to the conclusion that the Stolypin reforms were as misconceived in economic terms as they turned out to be politically (pp. 175-78). Many readers (this reviewer included) will be ideologically predisposed to hope that Kingston-Mann succeeds in her vindication of la petite culture, but in fact it is still too early to imagine that the jury has come in.

HEATH PEARSON, University of California, Berkeley

Hitler's Economy: Nazi Work Creation Programs, 1933-1936. By Dan P. Silverman. Cambridge, MA: Harvard University Press, 1998. Pp. 384. \$45.00.

This book deals with the early phases of the Nazi recovery and the role of work creation and highway construction. It is mainly a study of the political process underlying the preparation and implementation of work-creation programs between 1933 and 1936. Silverman bases his research on archival sources, mainly at the regional and local levels. Although quantitative research is clearly not the author's field, efforts are made to produce statistical material. This is reflected in the appendix tables on circulation of work-creation bills and the sources of Autobahn finance, all taken from archival sources.

The book begins by asking whether the recovery of the German labor market in the 1930s was not a statistical artifact created by manipulation of official labor-market statistics. A strand of scholarly debate in the 1970 s had proposed just this hypothesis, pointing to various inconsistencies and changes in reporting habits in Germany's labor statistics at that time. Silverman traces this argument in detail and with apparent sympathy, only to conclude quite rightly in the end that the discrepancies in question are too small to account for the reduction in unemployment between 1933 and 1936 (from some 5.9 million to about 1.6 million).

The next chapters center around the financing techniques and the conceptual roots of German work-creation policies. This is probably one of the less satisfactory parts of the book, partly because the economic issues are not always addressed very clearly, partly because the coverage of existing research on this issue is quite selective. The study then shifts its focus to regional and local aspects, and it is here that Silverman is making a genuine contribution: as he demonstrates from an impressive variety of local archival sources, work-creation programs in Nazi Germany were not so much the realization of a centrally conceived master plan as an umbrella stretched over a wide diversity of locally and regionally defined work-creation schemes. 
One major exception to this rule was Autobahn construction, which was indeed organized centrally under the aegis of a special administrator, Fritz Todt. The propensity for grand design and the alleged efficiency of Todt and his labor squads have often been mystified, and even Silverman's treatment of his impact on highway construction is not entirely free of such myths. Here, limitations to Silverman's coverage of the literature come to be felt. He gets stuck in side issues such as the alleged military usefulness of the Autobahns (which would be minimal in a small country with a dense and efficient railway network). But he is back on track when he concludes that the Autobahn project was too small and gained momentum too late to play a role in the Nazi recovery. In passing it may be noted that contrary to the book's conclusions, its front cover, showing a Nazi advertisement for the Volkswagen Beetle on a new and empty motorway, again conveys the old myths. (Beetles arrived to make their buyers' houses look bigger only after World War II. Closer inspection shows that the advertisement dates from 1936, when work creation had already ended and Autobahn construction had merely started to pick up).

The book enters into its most challenging topic when it comes to assessing the impact of work creation on the pace of the Nazi recovery. This question is obviously hard to answer on the basis of political discourse, which is the preferred method in other parts of the book. The author tackles this problem by venturing a rather explicit economic comparison of Germany's performance to the recoveries in Britain and the United States. This idea is clearly a good one, but a more explicit analytical framework would have been desirable, as the author's position appears to shift between various hypotheses and consequently remains ambiguous. Observing that fiscal policy in those countries was on the whole rather more conservative than in Germany at the time, he concludes that the greater fiscal stimulus in Germany must have triggered the more vivid recovery. On the other hand he notes that the direct employment effects of work creation must have been rather limited, and concludes that other forces of recovery must have been at work. Whether or not recovery was self-sustained remains unclear, although his tendency is to adopt a skeptical stance on this question.

In sum, this book is largely the attempt to address analytical issues in the Nazi recovery with the tools of an archival historian, and the results are mixed. Had the author restrained himself to an archival account of the political process behind work creation, the results could have been more convincing. In its present form, the book covers the politics of work creation only in part. It is at its best in the often detailed case studies of the regional aspects of work-creation policies, and its archival coverage of these is impressive. However, much of the decision-making process at the central-government level still waits to be explored, even after this book.

ALBRECHT RITSCHL, University of Zürich

\section{ASIA, AFRICA, AND LATIN AMERICA}

La economía argentina en el largo plazo: ensayos de historia económica de los siglos XIX y XX. By Roberto Cortés Conde. Buenos Aires: Editorial Sudamericana-Universidad de San Andrés, 1997. Pp. 253. No price available.

In two seminal books (El progreso argentino, 1880-1914 [Buenos Aires: Sudamericana, 1979]) and Dinero, deuda y crisis: evolución fiscal y monetaria en la Argentina, 18621890 [Buenos Aires: Sudamericana, 1989]), Roberto Cortés Conde not only significantly enriched our knowledge of the economic history of Argentina during the decades of dizzy- 